\title{
Aumento acetabular pela técnica de Stahelli modificada
} Acetabular increase with modified Stahelli technique

\section{Sílvio Pereira Coelho ; Joäo Francisco Comnimos Corrêa ${ }^{2}$; Leonardo do Nascimento ${ }^{2}$}

\section{RESUMO}

Os autores apresentam neste trabalho um estudo retrospectivo realizado em 18 pacientes submetidos a tratamento cirúrgico de insuficiência acetabular pela osteotomia da pelve seguindo a técnica descrita por Lynn T. Staheli. Enfatizam a modificação da técnica deste autor, com a introdução do enxerto ósseo, retirado da tábua externa do ilíaco, numa fenda aprofundada até cerca da cortical interna do ilíaco. Os pacientes foram acompanhados através de consultas ambulatoriais previamente a cirurgia e pós-operatoriamente com seguimento que variou de 2 meses a 4 anos no serviço de ortopedia infantil do Hospital Independência - Complexo Hospitalar ULBRA/Porto Alegre-RS. O objetivo do trabalho foi avaliar o quadril acometido pré e pós-operatoriamente, demonstrando a evolução e vantagens da variação da técnica de Staheli desenvolvida neste serviço. Observou-se que a cirurgia, se realizada sob técnica adequada e em mãos experientes, torna-se uma fonte válida de tratamento para aquelas patologias que levam a uma insuficiente cobertura da cabeça femoral.

Descritores: Aumento acetabular, osteotomia da pelve.

\section{SUMMARY}

The authors present in this paper a retrospective study of eighteen patients treated surgically for insufficiency of the acetabular coverage with the shelf procedure according to Lynn T. Staheli. This study was done at the Service of Pediatric Orthopedics of Hospital Independência - Complexo Hospitalar $U L B R A / P o r t o$ Alegre-RS. They call attention to the modification of the surgical technique in that the bone graft taken from outer cortex of the iliac bone, is deepened in the slot in the superior rim of the acetabulum. The follow-up ranged from two months to four years. The aim of this paper was to evaluate the affected hip pre and postoperatively showing the results and the advantages of the modified shelf technique. They observed that if the surgery is performed according to the correct technique and by an experienced surgeon, it is a very good alternative to the treatment of those orthopedics diseases that lead to an insufficient coverage of the femur head.

Key words: acetabular augmentation, shelf, pelvic osteotomy.

\section{INTRODUCTION}

The treatment of the insufficiency of the acetabular coverage of the femoral head, caused by acetabular alterations or subluxation of the proximal femoral epiphysis, is a considerable challenge to the orthopedic surgeon. In the literature there are countless techniques and variations to solve this problem. The procedure that uses bone graft as a "shelf" in the superior rim of the acetabulum was commonly used during the first half of this century aiming an increase the acetabular surface in those cases of dysplasia of the acetabular development. However, during the last decades major emphasis was given to the pelvic redirectional osteothomy and to the displacement osteothomy.

1- Médico ortopedista e traumatologista, membro titular da SBOT, chefe do serviço de Ortopedia Pediátrica do Hospital Independência - ULBRA/RS. 2- Médico residente do $3^{\circ}$ ano em ortopedia e traumatologia do Hospital Independência - ULBRA/RS.

Endereços para correspondência:
Rua João Manoel Guedes Falcão, 821 - CEP. 5040-000 - Caxias do Sul - RS ou Av. Bagé, 1259 Ap. 401 - CEP 90460-080 - Porto Alegre -RS 
A técnica cirúrgica defendida por Lynn T. Stahelli foi descrita por este autor como um tipo de procedimento em prateleira (Slotted Acetabular Augmentation)5. Trata-se de técnica com metodologia simples que aumenta a extensão de congruência articular através de aumento acetabular que pode facilmente ser controlado pelo cirurgião. Inúmeras patologias alteram a congruência articular ao nível do quadril, principalmente na infância. Indicação definida para esta técnica é naqueles quadris com congruência não esférica ou com deficiência extrema $a^{3,4,5,7}$. Uma indicação secundária é a situação em que o cirurgião leva em conta a simplicidade e a facilidade desta técnica em relação as demais. Contra indicações incluem quadris displásicos com congruência esférica com indicação de osteotomia redirecional ${ }^{1}$, 3. Na literatura brasileira, não encontramos até o momento nenhum trabalho concernente ao assunto. Baseados na experiência adquirida nesta técnica, desenvolvemos em nosso serviço variações no procedimento descrito por Stahelli. Outrossim, nas nossas indicações, a patologia de Legg-CalvéPerthes teve um lugar especial. Acreditamos que o aumento do acetábulo é um procedimento seguro, fácil de ser realizado e de bons resultados funcionais para aqueles casos de pacientes com moléstia de Perthes que necessitam de cobertura para uma cabeça femoral subluxada. Os objetivos do nosso trabalho são apresentar a variação de técnica por nós desenvolvida, as facilidades que estas geraram no cuidado pós-operatório dos pacientes e os resultados que obtivemos.

\section{CASUÍSTICA E MÉTODOS}

Foram avaliados retrospectivamente uma série de 18 pacientes submetidos a osteotomia acetabular pela técnica de Stahelli modificada no período de 09/95 a 06/99. Com a intenção de delinear o perfil clínico desses pacientes, foram avaliados: sexo, raça, lado acometido, idade, patologia envolvida na queixa principal e procedimentos prévios.

Dos 18 pacientes analisados 7 (38,8\%) eram do sexo masculino e $11(61,2 \%)$ do sexo feminino. As idades variaram entre 8 e 13 anos na última revisão com média de 10,6 anos. Destes, 14 pacientes $(77,7 \%)$ eram brancos e apenas $4(22,3 \%)$ eram negros. Com relação ao diagnóstico inicial, 9 (50\%) tinham doença de Legg-Calvé-Perthes, 8 (44,4\%) com displasia acetabular congênita e 1 (5,5\%) com displasia epifisária múltipla (Gráfico1). As patologias acometiam o lado direito em 10 pacientes $(55,5 \%)$ e o esquerdo em 8 (44,5\%) (Tabela 1).

Os pacientes foram avaliados através de exame radiográfico de bacia panorâmico em AP e Louenstein pré e pós-operatoriamente, usando-se o ângulo de Wiberg (CE angle - valor normal de 35 graus) como determinante do grau de cobertura acetabular.
The surgical technique proposed by Lynn T. Stahelli was described as a kind of procedure of slotted acetabular augmentation. This is a technique with simple methodology that increases the extension of the articular surface through an increase of the acetabular surface that can be easily controlled by the surgeon. Several pathologies modify the articular surface in the hip joint, mainly during the childhood. The definitive indication for the above technique would be nonspheric hip articulation or extreme deficiency $3,4,5,7$. Another indication is when the surgeon take into account the simplicity and easiness of this technique compared to the other ones available. Contraindications include dysplastic hips with spheric surface where the redirectional osteothomy is indicated ${ }^{1.3}$. In the Brazilian literature, up to this moment we could not find any publication related to this subject. Based in the experience gained with this technique, we developed in our Service modifications to the procedure described by Stahelli. Thus, in our indications the pathology of Legg-Calvé-Perthes had a special place. We believe that the increase of the acetabulum is a safe procedure, easy to be performed and with good functional results in those cases of patients with Perthes disease who need coverage for a subluxed femoral head. The objectives of our work are to present the modification of the technique developed by our team, the consequent benefits in the postoperatory phase and the results obtained.

\section{MATERIAL AND METHODS}

Retrospectively, 18 patients underwent a acetabular ostethomy according to the modified Stahelli technique fromSeptember/95 to June/99. The clinical characteristics of these patients were defined by: race, gender, side of the dysfunction, pathology related to the principal complaint and previous procedures.

Seven $(38,8 \%)$ of the 18 patients evaluated were males and 11 $(61,2 \%)$ were females. The age ranged from 8 to 13 years old with average of 10,6 years old. Fourteen (77,7\%) were white and only $4(22,3 \%)$ black. With respect to the initial diagnosis, 9 (50\%) had Legg-Calvé-Perthes disease, $8(44,4 \%)$ had congenital acetabular dysplasia and 1 (5,5\%) had multiple epiphisial dysplasia (Graphic 1). The pathologies were in the right side in $10(55,5 \%)$ patients and left side in 8 (44,5\%) patients (Table 1)

The patients were evaluated trough a panoramic antero-posterior and Lounstein

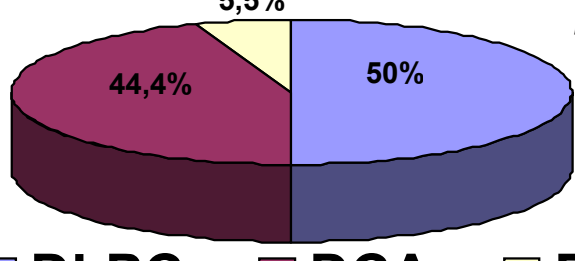
radiographic examination of the hip before and after surgery, with the use of Wiberg angle (CE angle - normal value 35 degrees) as determinant of the degree of acetabular coverage.

\section{$\square$ DLPC $\square$ DCA $\square$ DEM}

Gráfico 1- Distribuição das patologias que originaram a lesão.

Graphic 1-Distribution of the pathologies which caused the disfunction 
Tabela 1

Table 1

Distribuição dos pacientes segundo idade, sexo, cor, lado acometido, procedimento prévio Distribution of patients according to age, gender, race, affected side, previous procedure

\begin{tabular}{|c|c|c|c|c|c|c|}
\hline$\overline{\mathrm{N}^{\circ}}$ & Controle & Idade & Sexo & Cor & Lado Acometido & Procedimento Prévio \\
\hline \# & Initials & Age & Gender & Race & Affected side & Previous procedure \\
\hline 1. & P.S.R.L. & 12 & $\mathrm{~F}$ & $\mathrm{~B} / \mathrm{W}$ & $\mathrm{D} / \mathrm{R}$ & S- Osteot. Salter \\
\hline 2. & P.O.A. & 10 & $M$ & $\mathrm{~B} / \mathrm{W}$ & $E / L$ & $\mathrm{~N}$ \\
\hline 3. & V.R.C. & 10 & $M$ & $\mathrm{~B} / \mathrm{W}$ & $\mathrm{D} / \mathrm{R}$ & $\mathrm{N}$ \\
\hline 4. & D.V. & 13 & $\mathrm{~F}$ & $\mathrm{~B} / \mathrm{W}$ & $\mathrm{D} / \mathrm{R}$ & S- Osteot. Salter \\
\hline 5. & L.N. & 11 & $\mathrm{M}$ & B/W & $E / L$ & $\mathrm{~N}$ \\
\hline 6. & A.F.P.S. 15 & $\mathrm{~F}$ & $\mathrm{~B}$ & E/W & & S- Osteot. Salter \\
\hline 7. & T.M. & 8 & $\mathrm{~F}$ & N/B & $E / L$ & $\mathrm{~N}$ \\
\hline 8. & J.S.B. & 9 & $M$ & $\mathrm{~B} / \mathrm{W}$ & $\mathrm{D} / \mathrm{R}$ & $\mathrm{N}$ \\
\hline 9. & A.M.S.S. & 10 & $\mathrm{~F}$ & B/W & $E / L$ & $\mathrm{~N}$ \\
\hline 10. & T.G.S. & 11 & $\mathrm{~F}$ & N/B & $\mathrm{D} / \mathrm{R}$ & S- Osteot. Salter \\
\hline 11. & D.S. & 9 & $M$ & $\mathrm{~B} / \mathrm{W}$ & $E / L$ & $\mathrm{~N}$ \\
\hline 12. & M.C.R. & 10 & $\mathrm{~F}$ & $\mathrm{~B} / \mathrm{W}$ & $D / R$ & $\mathrm{~N}$ \\
\hline 13. & C.F.R. & 8 & $\mathrm{~F}$ & N/B & $\mathrm{D} / \mathrm{R}$ & $\mathrm{N}$ \\
\hline 14. & M.O. & 9 & $M$ & $\mathrm{~B} / \mathrm{W}$ & $\mathrm{D} / \mathrm{R}$ & $\mathrm{N}$ \\
\hline 15. & N.A.F. & 11 & $\mathrm{~F}$ & $\mathrm{~B} / \mathrm{W}$ & $\mathrm{E} / \mathrm{L}$ & $\mathrm{N}$ \\
\hline 16. & D.A.B. & 10 & $\mathrm{~F}$ & N/B & $\mathrm{E} / \mathrm{L}$ & $\mathrm{N}$ \\
\hline 17. & C.B. & 12 & $\mathrm{~F}$ & $\mathrm{~B} / \mathrm{W}$ & $\mathrm{D} / \mathrm{R}$ & S- Osteot. Salter \\
\hline 18. & N.C. & 13 & $M$ & $\mathrm{~B} / \mathrm{W}$ & $\mathrm{D} / \mathrm{R}$ & $\mathrm{N}$ \\
\hline
\end{tabular}

Os pacientes avaliados pré operatoriamente apresentavam como queixas principais dor no quadril acometido em 16 (88,8\%), claudicação em 17 (94,4\%), limitação de rotação interna e externa em todos os pacientes avaliados, limitação da abdução e adução em 16 pacientes (88,8\%), limitação de flexão em 13 pacientes (72,2\%) (Gráfico 2).
Evaluated before surgery patients presented with main complaint pain in the affected hip side in 16 (88,8\%), claudication in 17 (94,4\%), limited internal and external rotation in all patients evaluated, limited abduction and aduction in 16 patients (88,8\%), limited flexion 13 patients (72,2\%) (Graphic 2).

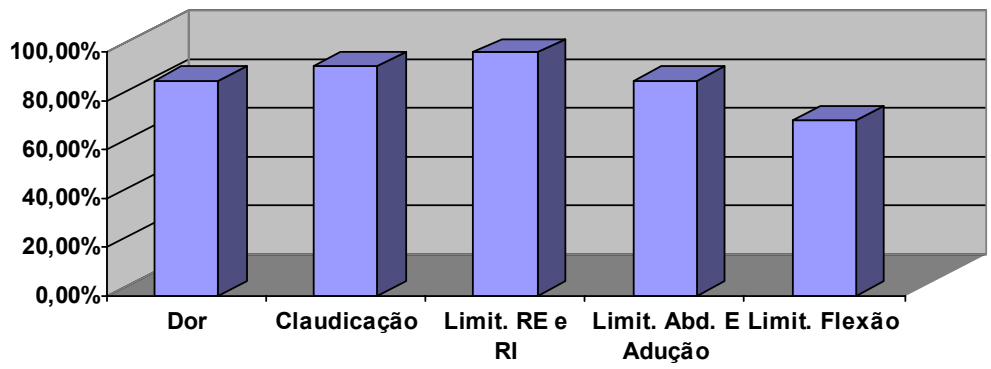

Gráfico 2 - Distribuição dos sintomas pré-operatórios. Graphic 2 - Distribution of the preoperatory symptoms

Técnica: O paciente deve estar em decúbito dorsal com coxim que eleve o lado afetado cerca de 15 graus. Faz-se uma incisão em "biquini" $1 \mathrm{~cm}$ abaixo e paralelo à crista ilíaca, expondo-se a articulação do quadril através de uma abordagem iliofemoral. O tendão da porção reflexa do reto femoral é identificado, dissecado em sua extensão e reparado após secção. A cápsula é identificada sem ser aberta. A fenda realizada para o aumento acetabular é feita na margem deste através de
Technique: The patient must be in dorsal supine position with a support elevating the affected side in 15 degrees. An incision "bikini" type $1 \mathrm{~cm}$ below and paralel to the iliac crest, exposing the hip joint through na approach ileofemoral. The tendon of the reflex portion of the femoral rectus is identified, dissected in its extension and repaired after the section. The capsule is identified but not opened. The slot performed to acetabular increase is done in its margin with osteosthomy with depth greater than the one 
osteótomo com profundidade maior que a descrita por Stahelli, para que o enxerto tenha maior estabilidade. Após realiza-se decorticação da porção lateral da asa do ilíaco conseguindo-se um enxerto ósseo córtico esponjoso retangular com tamanho suficiente para a cobertura da cabeça femoral. O enxerto é então colocado sob impacção profundamente na fenda realizada na margem acetabular. Enxerto ósseo esponjoso adicional é retirado do ilíaco, criando pequenos pedaços que serão colocados sobre a prateleira córtico esponjosa. Esta camada de enxerto esponjoso é mantida pela porção reflexa do reto femoral reconstituída (Fig.1). Radiografias de controle são realizadas e faz-se o fechamento através de sutura dos planos. Na grande maioria dos pacientes não usamos gesso no pós operatório, dado a estabilidade conseguida na colocação do enxerto. O paciente permanece sem apoio por período de 8 semanas, iniciando apoio parcial por mais 2 a 4 semanas e então é liberado para apoio total.

\section{RESULTADOS}
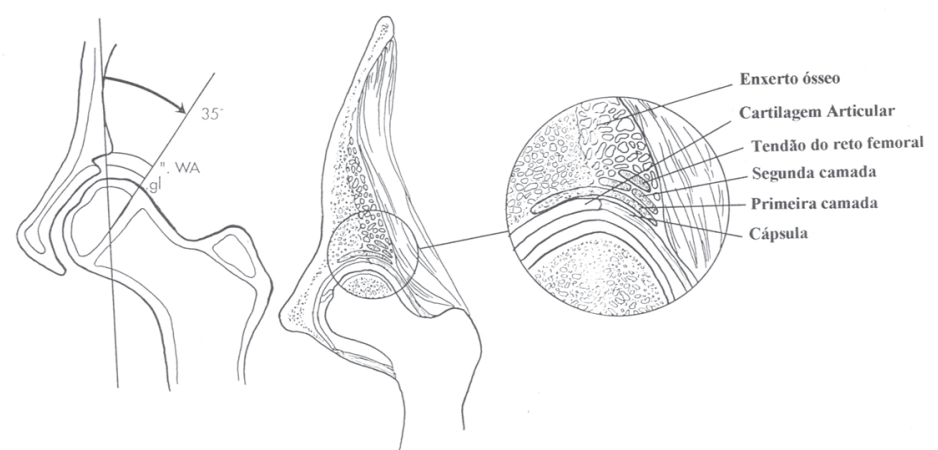

Figure 1: Acetabular increase with modified stahelli technique described by Staelli, aiming greater stability of the graft. After that the lateral portion of the iliac wing is decorticated to get a retangular bone graft, big enough for the coverage of the femoral head. Then, the graft is placed under impact deeply in the slot of the acetabular margin. Additional spongiosus bone graft is collected from the iliac, forming small pieces that will be placed over the cortico espongiosus shelf. This layer of graft is mantained by the reflex portion of the reconstructed femoral rectus (Fig. 1). Control X-rays are performed and the closing is performed with suture of the layers. In the majority of our patients cast is not used in the postoperatory days, since stability is achieved with the placement of the graft. The patient remains without support for 8 weeks, starting partial support during additional 2 to 4 weeks and full support thereafter.
O tempo de seguimento dos pacientes variou de 2 meses a 4 anos, tendo todos os pacientes boa integração do enxerto. A avaliação clínica realizada após 8 semanas antes da liberação para o apoio, mostrou diminuição de rotação interna de 5 graus em 7 pacientes $(38,8 \%)$ e rotação externa de 10 graus em 10 pacientes (55,5\%); limitação de abdução leve em todos os pacientes com índice que variou de 10 a 18 graus comparado ao lado oposto; flexão mantida em todos os pacientes; sinal de Thomas positivo em 7 pacientes $(38,8 \%)$ e encurtamento de isquiotibiais em apenas 1 paciente (5,5\%). A melhora de amplitude de movimentos ocorreu em todos os pacientes com follow-up maior que 6 meses (Fig. 2,3).

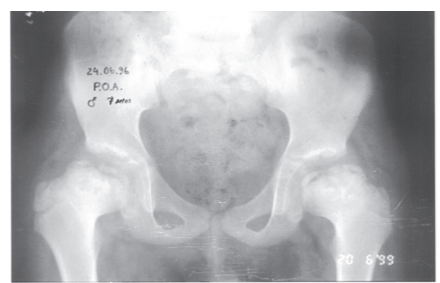

Figure 2

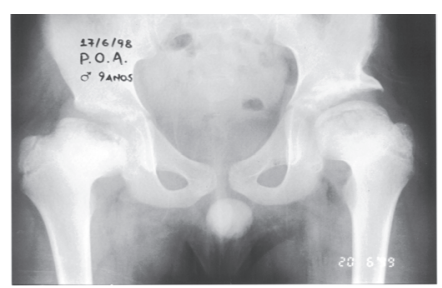

Figure 3
The follow up time ranged from 2 months to 4 years, having all patients good adherence of the graft. The clinical assessment performed after 8 weeks, before was permitted to the patient partial support, showed decrease of 5 degrees in the internal rotation in 7 (38,8\%) patients and 10 degrees in the external rotation in 10 (55,5\%) patients; mild limitation of the abduction in all patients with range of 10 to 18 degrees compared to the contralateral side; flexion was mantained in all patients; sign of Thomas positive in 7 (38,8\%) patients and shortening of isquitibials in just 1 (5,5\%) patient. The improvement of the movement amplitude occurred in all patients that had follow up for more than 6 months (Fig. 2,3).

Gráfico 3 - Principais alterações clínicas pós-operatórias. Graphic 3 - Principal clinical changes after surgery

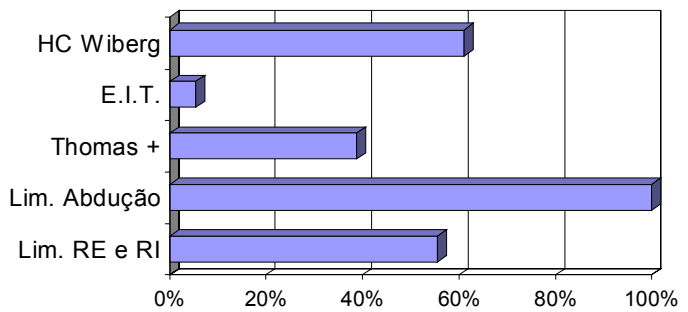

$\square$ Follow-up 
O ângulo de Wiberg, que pré-operatoriamente era de 22 graus (média) teve aumento significativo ficando em torno de 38 graus, com hipercorreção (ângulo maior de 35 graus, porém menor que 42 graus) em 11 pacientes (61,1\%) (Gráfico 3). Dos pacientes analisados, 5 usaram gesso pelve-podálico pós operatório, o que não demonstrou diferença significativa ao exame pós operatório quando relacionados aos demais pacientes. Tivemos 1 caso de dembulação precoce (3 semanas) em paciente com gesso, que não alterou o quadro radiológico (Fig.4, 5). Não houve outras complicações relacionadas ao procedimento.

Apresentaram boa cicatrização 100\% dos pacientes, com critério de satisfação pessoal (paciente e família) de bons resultados em 14 pacientes $(77,7 \%)$, e regulares em 4 (22,2\%), não obtendo nenhum resultado ruim.

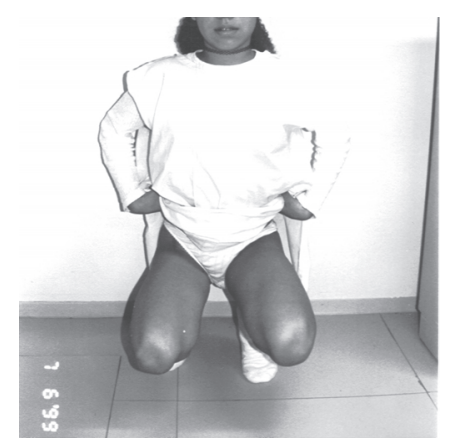

Figure 4

\section{DISCUSSÃO}

Dentre as inúmeras técnicas utilizadas para a deficiência de cobertura acetabular encontra-se a técnica de Stahelli. Tal procedimento tem sido utilizado com maior ênfase aqueles pacientes com displasia do desenvolvimento acetabular. No entanto, em nossa casuística, demonstrou-se as vantagens deste método nas falhas de cobertura cotilar ou subluxação da epífise femoral proximal em pacientes maiores de 8 anos com enfermidade de Perthes. Tais pacientes foram beneficiados devido a menor morbidade e menor número de complicações comparadas as demais técnicas com a mesma finalidade. Não observamos alterações significativas nos resultados obtidos até o momento quando observados sexo, cor ou lado acometido.

Osteotomia pélvica prévia pela técnica de Salter observada em alguns pacientes não demonstrou ser obstáculo para o sucesso do procedimento, porém deve-se ficar atento as possíveis modificações anatômicas ocorridas devido a intervenção prévia. A hipercorreção do enxerto demonstrou que pode ser aceito maior índice de correção e que os parâmetros antes estabelecidos podem ter maiores margens de cobertura acetabular sem alterações clínicas significativas. Devido a boa integração do enxerto ósseo posicionado mais profundamente no bordo acetabular, o aparelho gessado tornou-se necessário apenas em crianças com perfil social de difícil controle pelos pais, dentre eles um paciente com problemas auditivos.
Wiberg angle, in average 22 degrees before surgery, had a significant increase, increasing to circa 38 degrees, with hipercorrection (angle greater than 35 degrees, but smaller than 42 degrees) in $11(61,1 \%)$ patients (Graphic 3). Of the assessed patients 5 placed a pelvipodalic cast after surgery, what did not show significant difference in the postoperative examination when related to the other patients. We had a subject with cast that had precocious deambulation (3 weeks), what did not bring changes to the radiological picture (Fig. 4,5). There were no other complications related to the procedure.

All patients had good scarring, and the personal satisfaction (patient and family) with the results was good in 14 patients $(77,7 \%)$, and regular satisfaction in $4(22,2 \%)$. No patient considered the results as bad.

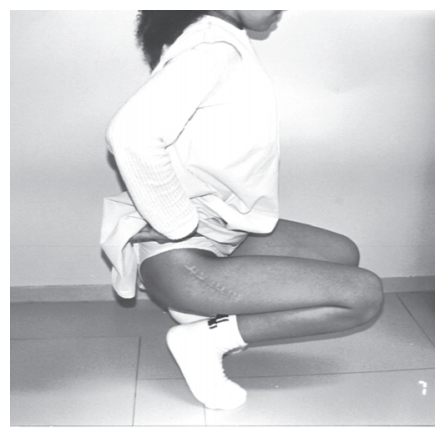

Figure 5

\section{DISCUSSION}

Among the several techniques used to correct insufficient acetabular coverage is the technique of Stahelli. This procedure is more frequently used in those patients with dysplasia of the acetabular development. However, in our experience, the advantages of this method were demonstrated in the the insufficient coverage of femoral head or subluxation of the femoral epiphisis in patients 8 or more years old with Perthes disease. These patients had benefit due to lower morbidity and less complications when compared to other techniques used to correct same abnormality. We did not observe significant alterations in the results when gender, race and involved side were considered.

Previous osteothomy with technique of Salter present in some patients was not an obstacle to the success of the procedure, however, attention must be given to the possible anatomic modifications secundary to the previous procedure. The hipercorrection of the graft has demonstrated that a greater correction index can be accepted and that the parameters set before can have bigger margins of acetabular coverage without significant clinical modifications. Due to the good integration of the bone graft placed more deeply in the acetabular rim, cast became necessary only for those children with behavior of difficult control by parents, among then one patient with hearing problems. 


\section{CONCLUSÕES}

Os resultados obtidos permitem-nos concluir que:

1) A técnica utilizada trata-se de método efetivo na correção do déficit de cobertura acetabular quando realizado seguindose as indicações previamente citadas.

2) A utilização desta técnica modificada quando comparada a resultados da técnica clássica de Stahelli demonstrou menor morbidade bem como resultados animadores e confiáveis.

3) Os pacientes com idade superior a 8 anos com enfermidade de Perthes com subluxação da cabeça femoral foram bastante beneficiados pelo procedimento, tornando-se um método efetivo para tal problema

4) A simplicidade da técnica nos encoraja a usá-la em pacientes com deficiência de cobertura acetabular poi baixos índices de complicações são constatados também por outros autores na literatura atual

\section{REFERÊNCIAS}

1. Beaty, J. H.: Congenital and Developmental Anomalies of Hip and Pelvis. Campbell Ortopedic Surgery 3:1049-1051, 1998.

2. Lyne, E.D.; Katcherian D.A.: Slotted acetabular augmentation in patients with neuromuscular disorders. J Pediatric Orth opedic 8: 278-84, 1988

3. Pemberton, P. A.: Pericapsular osteotomy for congenital dislocation of the hip: Indications na techniques. Some long-term results. Journal of Bone Joint Surgery (Am) 47:437-449, 1965

4. Smith, A. R.: The selving operation as an adjunct to open reduction in congenital dislocated hip and its use in paralytic and pathologic dislocation. Ann Surg 106:278292, 1937.

5. Stahelli, L. T.: Slotted Acetabular Augmentation. Journal of Pediatric Orthopedics 1:321-327, 1981

6. Stahelli, L.T.: Ampliação acetabular na displasia do quadril no adolesente. Tachdjan-Ortopedia Pediátrica 2:523-525, 1995.

7. Stahelli, L.T.; Chew D. E.: Slotted acetabular aumentation in childhood and adolescense. J Pediatric Orthopedic 12:569-80, 1992.

\section{CONCLUSIONS}

The results obtained allow us to conclude that:

1) The technique used is na effective method in the correction of the insufficient acetabular coverage when performed following the indications previously mentioned.

2) The use of this modified technique when compared to the results of the classic Stahelli technique did show lower morbidity with positive and reliable results.

3) Patients with age above 8 years old and with Perthes disease and subluxation of femoral head were well improved with this procedure, what shows this is a effective method to treat such problem.

4) The simplicity of the technique encourages us to use it in patients with insufficient acetabular coverage because a low number of complications is seen also by other authors in the existing literature. 